\title{
PEMANFAATAN JAMUR TANDAN KOSONG KELAPA SAWIT (Volvariellavolvacea) SEBAGAI BAHAN BAKU SOSIS SAPI
}

\section{UTILIZATION OF PALM OIL EMPTY BUNCHES MUSHROOM (Volvariellavolvacea) AS RAW MATERIAL FOR BEEF SAUSAGE}

\author{
Lina Widawati' ${ }^{1}$, Eva Ramalia Sari ${ }^{2)}$ \\ ${ }^{1)}$ Prodi Teknologi Pertanian, Fakultas Pertanian, Unived, Bengkulu \\ ${ }^{2)}$ SMK Negeri 6 Bengkulu Utara, J1 Bintuhan-Ketahun, Kec. Batik Nau, Bengkulu Utara \\ Email : lina84id@gmail.com
}

\begin{abstract}
ABSTRAK
Jamur merupakan sumber makanan yang memiliki kandungan gizi tinggi. Tingginya kandungan protein jamur tandan kosong kelapa sawit diharapkan dapat memberikan kontribusi nilai protein pada sosis sapi. Tujuan penelitian ini adalah untuk mengetahui pengaruh substitusi jamur tandan kosong kelapa sawit dengan tepung talas termodifikasi terhadap mutu sosis sapi. Metode dalam penelitian ini meliputi proses pembuatan tepung talas termodifikasi serta pengolahan sosis sapi dengan substitusi jamur tandan kosong kelapa sawit. Analisis penelitian ini meliputi kadar protein, tekstur serta sifat organoleptik sosis daging sapi. Hasil analisis kandungan protein sosis berkisar antara $13,15 \%$ hingga $16,02 \%$. Hasil analisis tekstur sosis berkisar antara 2,78 mm/gram detik hingga 4,41 $\mathrm{mm} /$ gram detik. Hasil penilaian uji organoleptik terhadap warna sosis tidak berbeda nyata pada semua perlakuan, panelis menilai warna sosis pada skala suka. Penilaian rasa sosis dengan rerata berkisar antara antara 3,30 (agak suka) hingga 4,30 (suka). Penilaian rerata tekstur sosis berkisar antara 3,00 (agak suka) hingga 4,40 (suka).
\end{abstract}

Kata Kunci :jamur tandan kosong kelapa sawit, sosis sapi, protein

\section{ABSTRACT}

Mushrooms are a food source that has high nutritional content. The high protein content of palm oil empty bunches mushroom is expected to contribute to the value of protein in beef sausage. The purpose of this study was to determine the effect of palm oil empty bunches mushroom substitution with modified taro flour on the quality of beef sausage. The methods in this study include the process of making modified taro flour and processing of beef sausages by substituting palm oil empty bunches mushroom. Analysis of this study included protein levels, texture and organoleptic properties of beef sausages. The results of the analysis of the sausage protein content ranged from $13.15 \%$ to $16.02 \%$. The results of the sausage texture analysis ranged from $2.78 \mathrm{~mm} / \mathrm{gram}$ seconds to $4.41 \mathrm{~mm} / \mathrm{gram}$ seconds. The results of the organoleptic test on the color of sausage were not significantly different in all treatments, the panelists assessed the color of sausage at the liking scale. Assessing the taste of sausages averaged between 3.30 (rather like) to 4.30 (likes). Rating of the average texture of sausage ranges from 3.00 (rather like) to 4.40 (likes).

Keywords: palm oil empty bunches mushroom, beef sausage, protein 


\section{PENDAHULUAN}

Sosis merupakan produk makanan yang diperoleh dari daging halus (mengandung daging tidak kurang dari $75 \%$ ) tepung atau pati dengan atau tanpa penambahan bumbu dan bahan tambahan makanan lain yang diizinkan dan dimasukkan kedalam selubung sosis (SNI01- 3820-1995). Dalam sosis, daging merupakan sumber protein yang berfungsi sebagai pengemulsi. Umumnya sosis dibuat dari daging sapi atau daging ayam, hal ini dikarenakan bahan tersebut banyak tersedia dipasaran dan disukai oleh semua kalangan usia. Melihat harga jual daging yang masih tergolong mahal, maka perlu dilakukan pengganti atau subtitusi dari bahan tesebut yaitu dengan menggunakan bahan dasar yang memiliki harga lebih ekonomis namun memiliki protein yang tinggi, yang salah satunya adalah jamur tandan kosong kelapa sawit.

Jamur merupakan sumber makanan yang memiliki kandungan gizi tinggi yaitu protein 3,8 gram; lemak 0,6 gram; serat 1,2 gram dalam 100 gram. Jamur sawit merupakan tumbuhan yang memanfaakan limbah pabrik kelapa sawit berupa tandan kosong kelapa sawit. Jamur sawit berwarna coklat abu-abu tumbuh pada tandan kosong kelapa sawit. Waktu muda berwarna abu-abu atau coklat dan berbentuk bulat-bulat seperti telur, tetapi ukuran bulatan ini lebih besar dari jamur merang. Jamur sawit biasa ditumis, dimasak dengan mie, atau dibuat sop. Tingginya kandungan protein jamur diharapkan dapat menggantikan protein hewani daging sapi pada sosis yang dihasilkan.

Dalam pembuatan sosis, biasanya ditambahkan bahan pengikat berupa tepung seperti tepung tapioka. Tepung tapioka memiliki tingkat elastisitas dan kandungan karbohidrat (pati) yang tinggi. Selain tepung tapioka, dapat juga digunakan tepung-tepung lainnya seperti tepung talas termodifikasi. Talas (Colocasia esculenta (L.) Schott) merupakan salah satu jenis umbi-umbian yang banyak di Indonesia, mudah didapatkan, memiliki. kandungan gizi yang cukup baik Tepung umbi talas mengandung gizi yang cukup tinggi dibandingkan dengan umbi - umbi yang lainnya. Kandungan kalsium (Ca) dan fosfor (P) dari tepung umbi talas cukup tinggi dan lebih tinggi dibandingkan beras (Richana, 2012). Menurut Fitriya (2012) kandungan karbohidrat talas berkisar antara 70-80\% sehingga umbi talas dapat digunakan sebagai sumber karbohidrat pendarnping beras. Melihat potensi yang dimiliki talas, maka talas dapat dibuat menjadi tepung yang nantinya akan diaplikasikan sebagai bahan 
pengikat dalam pembuatan sosis sapi yang memiliki karakteristik mutu yang diharapkan.

\section{METODE PENELITIAN}

\section{Bahan}

Bahan yang dibutuhkan dalam pengolahan sosis yaitu daging sapi, tepung tapioka, umbi talas, telur, garam, bawang putih, bawang merah, merica, batu es, kultur Bimo $\mathrm{CF}$ diperoleh dari Balai Besar Litbang Pascapanen Pertanian Bogor, serta jamur tandan kosong kelapa sawit yang didapat dari perkebunan kelapa sawit PT. Bio Nusantara Teknologi. Serta bahan-bahan untuk analisis.

\begin{abstract}
Alat
Alat yang dibutuhkan dalam proses pengolahan yaitu pisau, penggilingan, ayakan, blender, sendok, tirisan, baskom, timbangan, panci, dan kompor serta alat-alat untuk analisis.
\end{abstract}

\section{Pelaksanaan Penelitian}

Metode yang dilakukan dalam penelitian ini sebagai berikut:

1. Pengolahan tepung talas termodifikasi :

a. Persiapan Bahan Baku

b. Sortasi dan Pencucian

c. Pengupasan dan Pengirisan d. Perendaman dalam larutan Bimo-CF (5 grAM/5 liter air) selama 12 jam. Setelah itu dilakukan penirisan selama 2 menit (Haryadi, 2011)

e. Penjemuran di bawah sinar matahari selama 3 hari

f. Penggilingan dan pengayakan

2. Pengolahan sosis

a. Daging sapi 300 gram, 200 gram dan 100 gram dibersihkan dari kotoran dan darah dengan air bersih kemudian dipotong kecil-kecil

b. Jamur tandan kosong kelapa sawit di blansing selama 2 menit.

c. Daging digiling dengan penambahan jamur sawit sesuai perlakuan yaitu 100 gram, 200 gram dan 300 gram serta penambahan es batu sebanyak $15 \%$.

d. Daging giling dicampurkan dengan perbandingan tepung tapioka dan tepung talas termodifikasi dengan perlakuan masing-masing (10\%: 0\%) dan (5\%: $5 \%)$ diaduk rata.

e. Daging ditambahkan dengan bumbu bawang merah $10 \%$, bawang putih $10 \%$, garam $2,5 \%$, merica $10 \%$, telur $2 \%$ dan diaduk hingga rata.

f. Adonan dimasukkan dalam casing kemudian dikukus selama 30 menit.

g. Sosis dianaliss kadar protein, tekstur dan sifat organoleptik. 


\section{Metode Penelitian}

Rancangan yang digunakan dalam penelitian ini yaitu Rancangan Acak Kelompok (RAK) dengan dua faktor yaitu penambahan jamur jamur tandan kosong kelapa sawit dan tepung talas termodifikasi dengan perlakuan sebagai berikut:

Perlakuan perbandingan daging sapi dan jamur jamur tandan kosong kelapa sawit: D1 = Daging sapi 300 gram : Jamur tandan kosong kelapa sawit 100 gram D2 = Daging sapi 200 gram : Jamur tandan kosong kelapa sawit 200 gram D3 = Daging Sapi 100 gram : Jamur tandan kosong kelapa sawit 300 gram Perlakuan perbandingan tepung tapioka dan tepung talas termodifikasi

$\mathrm{T} 1=$ Tepung tapioka $30 \%:$ Tepung talas termodifikasi $0 \%$

$\mathrm{T} 2=$ Tepung tapioka $15 \%:$ Tepung talas termodifikasi $15 \%$

Jadi, perlakuan yaitu D1T1, D1T2, D2T1, D2T2, D3T1, D3T2.

Sebagai kontrol dibuat sosis dengan komposisi Daging sapi 400 gr : Tepung Tapioka $30 \%$

\section{Analisis Penelitian}

Analisis penelitian yang dilakukan adalah kadar protein dan tekstur sosis serta uji organoleptik dengan parameter penilaian terhadap warna, rasa, aroma dan tekstur dengan menggunakan panelis agak terlatih sebanyak 20 panelis.

\section{HASIL DAN PEMBAHASAN}

\section{Analisis Rendemen Tepung Talas} Termodifikasii

Rendemen

merupakan

perbandingan berat produk yang diperoleh terhadap berat bahan baku yang digunakan. Perhitungan rendemen dilakukan berdasarkan berat kering bahan. Rendemen tepung menyatakan nilai efisiensi dari proses pengolahan sehingga dapat diketahui jumlah tepung yang dihasilkan dari bahan dasar awalnya. Menurut (Indriyani, dkk. 2013) rendemen dinyatakan dalam persentase berat produk akhir yang dihasilkan per berat bahan olahan.

Dalam pengolahan tepung talas termodifikasi bahan baku umbi talas yang digunakan sebanyak $5 \mathrm{~kg}$ yang di jadikan bobot awal (V1). Umbi talas dijemur selama 3 hari dan digiling sehingga menghasilkan berat tepung 900 gram di jadikan sebagai berat hasil olahan (V2). Perhitungan rendemen tepung talas termodifikasi sebagai berikut

$$
\begin{aligned}
& \text { Berat Olahan (V1) = } 5000 \text { gram } \\
& \text { Berat Hasil Olahan (V2) } \quad=900 \text { gram } \\
& \text { Rendemen \% }=900 \mathrm{~g} / 5000 \mathrm{~g} \times 100 \% \\
& =18 \%
\end{aligned}
$$


Dari hasil analisis rendemen tepung talas termodifikasi menunjukkan nilai rendemen $18 \%$. Menurur Rahmawati, dkk (2012) tepung talas termodifikasi merupakan hasil penggilingan umbi talas yang dikeringkan. Hasil penelitian menunjukkan rata-rata rendemen pembuatan tepung talas termodifikasi adalah 19.7\%. Densitas kamba tepung talas termodifikasi adalah $0.534 \mathrm{~g} / \mathrm{ml}$. Derajat putih tepung talas termodifikasi dipengaruhi oleh warna umbi talas. Terdapat hubungan positif antara derajat putih dan tingkat kehalusan. Semakin tinggi tingkat kehalusan tepung, didapatkan nilai derajat putih tepung talas termodifikasi yang semakin tinggi. Sudut peluncuran dari tepung talas termodifikasi adalah $34^{\circ}$. Warna tepung talas termodifikasi relatif lebih gelap, kasar, dan kering dibandingkan dengan tepung terigu protein sedang. Kandungan kadar air pada talas mentah yaitu sebesar $69,2 \%$ (DKBM, 2005), rendemen tepung yang dihasilkan ditentukan oleh lama dan suhu pengeringan yang digunakan dalam pengeringan bahan sebelum penepungan. Semakin lama pengeringan yang digunakan, maka kadar air bahan akan semakin rendah dan menurunkan bobot bahan, sehingga rendemen tepung yang dihasilkan semakin rendah (Indriyani dkk, 2013).

\section{Kadar Protein Sosis}

Hasil analisis kandungan protein sosis dengan perbandingan daging sapi : jamur tandan kosong kelapa sawit (300 gram : 100 gram), (200 gram : 200 gram) dan (100 gram : 300 gram) serta perlakuan perbandingan tepung tapioka : tepung talas termodifikasi (30\%: $0 \%)$ dan $(15 \%$ : 15\%) ditampilkan pada tabel 1.

Tabel 1 menjelaskan rerata analisis kadar protein sosis berkisar antara $13,15 \%$ hingga $16,02 \%$. Hasil analisis kandungan protein sosis pada perlakuan perbandingan daging sapi dan jamur tandan kosong kelapa sawit terdapat perbedaan yang nyata pada taraf signifikan 5\%, namun pada perlakuan perbandingan tepung tapioka dan tepung talas termodifikasi tidak berbeda nyata. Hasil analisis kadar protein sosis sapi diperoleh bahwa kadar protein tertinggi pada perlakuan kontrol atau perbandingan daging sapi : jamur sawit 100 : 0 gram sebesar $16,02 \%$. Sedangkan kadar protein terendah pada perlakuan perbandingan daging sapi dan jamur sawit 100 : 300 gram yaitu 13,15\%. 
Tabel 1. Rerata Analisis Kadar Protein Sosis

\begin{tabular}{|c|c|c|}
\hline Perlakuan & \multicolumn{2}{|c|}{ Protein (\%) } \\
\hline Daging Sapi : Jamur Tandan & $\begin{array}{r}\text { Tepung Tapioka : Tepung Talas } \\
\text { Termodifikasi }\end{array}$ \\
\cline { 2 - 3 } Kosong Kelapa Sawit & $30 \%: 0 \%$ & $15 \%: 15 \%$ \\
\hline 400 gram : 0 gram (kontrol) & $16,02^{\mathrm{a}}$ & $15,15^{\mathrm{b}}$ \\
\hline 300 gram : 100 gram & $15,16^{\mathrm{b}}$ & $14,18^{\mathrm{c}}$ \\
\hline 200 gram : 200 gram & $14,12^{\mathrm{c}}$ & $13,20^{\mathrm{d}}$ \\
\hline 100 gram : 300 gram & $13,15^{\mathrm{d}}$ & \multicolumn{2}{|c|}{} \\
\hline
\end{tabular}

Ket : Angka yang diikuti oleh kode huruf yang berbeda menunjukkan adanya perbedaan yang nyata pada taraf signifikansi $5 \%$.

Penetapan kandungan protein perlu dilakukan untuk mengetahui kondisi bahan pangan makanan yang dibandingkan dengan kondisi standar. Syarat mutu sosis berdasarkan SNI 013820-2005 yang menyatakan syarat minimal kandungan protein sosis adalah 13,0\%. Dari hasil penelitian pada pembuatan sosis sapi dengan subtitusi jamur tandan kosong kelapa sawit dari semua perlakuan menunjukkan bahwa kandungan protein sosis sapi memenuhi standar karena kandungan protein diatas $13,0 \%$.

Semakin rendah penggunaan daging sapi dan semakin tinggi penggunaan jamur sawit pada pengolahan sosis maka kandungan kadar protein semakin rendah. Sedangkan perlakuan perbandingan tepung tapioka dan tepung talas termodifikasi tidak memberikan pengaruh terhadap kandungan protein sosis. Kadar protein sosis dipengaruhi oleh kadar protein pada bahan baku pada proses pengolahan, semakin rendah penggunaan daging sapi pada penggolahan sosis dan semakin tinggi penggunaan jamur sawit maka semakin rendah kadar protein pada sosis. Hal ini karena daging sapi memiliki kadar protein lebih tinggi dibandingkan dengan jamur sawit. Kadar protein daging sapi mencapai 18,80 g per $100 \mathrm{~g}$ bahan (Sudarisman dan Elvina, 1996) sedangkan jamur tandan kosong kelapa sawit 5,60\% (hasil analisis bahan baku).

Perlakuan penambahan tepung tapioka dan tepung talas termodifikasi tidak memberikan pengaruh yang nyata terhadap kandungan protein sosis karena protein tepung tapioka dan tepung talas termodifikasi hampir sama. Kadar protein 
pada tepung tapioka 1,1 \% (Suprapti, 2005) sedangkan protein talas $1,5 \%$ (Direktorat gizi Depkes RI,1981) sedangkan daging merupakan sumber protein yang dominan dibandingkan dari tepung (Soeparno, 1998).

\section{Tekstur Sosis}

Hasil analisis tekstur sosis dengan perbandingan daging sapi : jamur tandan kosong kelapa sawit (300 gram : 100 gram), (200 gram : 200 gram) dan (100 gram : 300 gram) serta perlakuan perbandingan tepung tapioka : tepung talas termodifikasi (30\%: 0\%) dan (15\%: 15\%) ditampilkan pada tabel 2.

Tabel 2 menjelaskan rerata analisis tekstur sosis dengan perlakuan kontrol tidak berbeda nyata terhadap perlakuan perbandingan daging sapi : jamur tandan kosong kelapa sawit (300 gram : 100 gram) serta perlakuan perbandingan tepung tapioka : tepung talas termodifikasi (30\%: 0\%) dan (15\%:15\%) akan tetapi berbeda nyata pada perlakuan perbandingan daging sapi : jamur tandan kosong kelapa sawit (200 gram : 200 gram) dan (100 gram : 300 gram) dengan penambahan tepung tapioka : tepung talas termodifikasi (30\%: $0 \%)$ dan $(15 \%$ : $15 \%)$ pada taraf signifikansi $5 \%$.

Rerata hasil analisis tekstur sosis dengan perbandingan daging sapi dengan substitusi jamur tandan kosong kelapa sawit berkisar antara 2,78 hingga 4,41 $\mathrm{mm}$ /gram detik. Semakin tinggi nilai tekstur maka tekstur sosis semakin lunak atau tidak kenyal. Perlakuan perbandingan daging dengan jamur memberikan pengaruh terhadap tekstur sosis, sedangkan perlakuan penambahan tepung tapioka dengan tepung talas termodifikasi tidak memberikan pengaruh yang nyata terhadap tekstur sosis. Tekstur sosis dipengaruhi oleh penggunaan bahan baku daging dimana semakin sedikit penggunaan daging sapi dan semakin tinggi penggunaan jamur tandan kosong kelapa sawit pada penggolahan sosis maka tekstur sosis semakin lunak atau tidak kenyal. Tekstur juga dipengaruhi oleh kadar protein pada sosis. Protein miosin banyak terkandung di dalam daging sapi. Protein miosin akan menggumpal dan membantu pembentukan gel sehingga menghasilkan tekstur yang kenyal (Hayuningsih dkk. 2009). Tingkat kekenyalan sosis dipengaruhi oleh kadar air yang terkandung di dalamnya. Sudarisman dan Elvina (1996) menjelaskan bahwa daging sapi memiliki kadar air $66 \%$ per $100 \mathrm{~g}$ bahan dan jamur memiliki kadar air 87,70\% per $100 \mathrm{~g}$ bahan (Karjono, 1992). 
Tabel 2. Rerata Analisis Tekstur Sosis

\begin{tabular}{|c|c|c|}
\hline Perlakuan & \multicolumn{2}{|c|}{ Tekstur (mm/gr detik) } \\
\hline Daging Sapi : Jamur Tandan & $\begin{array}{c}\text { Tepung Tapioka : Tepung Talas } \\
\text { Termodifikasi }\end{array}$ \\
\cline { 2 - 3 } Kosong Kelapa Sawit & $30 \%: 0 \%$ & $15 \%: 15 \%$ \\
\hline 400 gram : 0 gram (kontrol) & $2,78^{\mathrm{c}}$ & $3,07 \mathrm{c}$ \\
\hline 300 gram : 100 gram & $3,03^{\mathrm{c}}$ & $3,75 \mathrm{~b}$ \\
\hline 200 gram : 200 gram & $3,62^{\mathrm{b}}$ & $4,41 \mathrm{a}$ \\
\hline 100 gram : 300 gram & $4,35^{\mathrm{a}}$ & . \\
\hline
\end{tabular}

Ket : Angka yang diikuti oleh kode huruf yang berbeda menunjukkan adanya perbedaan yang nyata pada taraf signifikansi $5 \%$.

\section{Organoleptik Warna Sosis}

Hasil uji organoleptik warna sosis dengan perbandingan daging sapi : jamur tandan kosong kelapa sawit (300 gram : 100 gram), (200 gram : 200 gram) dan (100 gram : 300 gram) serta perlakuan perbandingan tepung tapioka : tepung talas termodifikasi $(30 \%: 0 \%)$ dan $(15 \%$ : 15\%) ditampilkan pada tabel 3 .

Tabel 3 menjelaskan rerata hasil uji organoleptik warna sosis, dimana perlakuan perbandingan daging sapi : jamur tandan kosong kelapa sawit serta penambahan tepung tapioka : tepung talas termodifikasi menujukkan tidak berbeda nyata pada taraf signifikasi 5\%. Panelis menilai warna sosis pada semua perlakuan substitusi jamur tandan kosong kelapa sawit dan penambahan tepung tapioka : tepung talas termodifikasi pada skala suka. Warna sosis yang di hasilkan yaitu coklat keputihan atau abu-abu. Warna pada sosis dipengaruhi oleh bahan yang digunakan. Salah satu bahan dasar dalam pembuatan sosis yang mempengaruhi aspek warna adalah daging sapi, karena memiliki warna merah cerah.

Menurut Sudrajat (2007) warna sosis sangat dipengaruhi oleh warna daging yang berhubungan dengan kandungan mioglobin pada daging, semakin tinggi kandungan mioglobinnya maka warna merah pada daging semakin gelap. Warna pada sosis juga dipengarui oleh bahan tambahan seperti pati yang digunakan dan substitusi jamur tandan kosong kelapa sawit yang berwarna kecoklatan sehingga dapat membentuk perubahan warna pada sosis. 
Tabel 3. Rerata Uji Organoleptik Warna Sosis

\begin{tabular}{|c|c|c|}
\hline Perlakuan & \multicolumn{2}{|c|}{ Warna } \\
\hline Daging Sapi : Jamur Tandan & $\begin{array}{r}\text { Tepung Tapioka : Tepung Talas } \\
\text { Termodifikasi }\end{array}$ \\
\cline { 2 - 3 } & $30 \%: 0 \%$ & $15 \%: 15 \%$ \\
\hline 400 gram : 0 gram (kontrol) & $4,10^{\mathrm{a}}$ & $4,00^{\mathrm{a}}$ \\
\hline 300 gram : 100 gram & $4,05^{\mathrm{a}}$ & $3,85^{\mathrm{a}}$ \\
\hline 200 gram : 200 gram & $3,90^{\mathrm{a}}$ & 3,95 \\
\hline 100 gram : 300 gram & $3,90^{\mathrm{a}}$ & \multicolumn{2}{|c|}{} \\
\hline
\end{tabular}

Ket : Angka yang diikuti oleh kode huruf yang berbeda menunjukkan adanya perbedaan yang nyata pada taraf signifikansi $5 \%$.

Ket Skala $: 1=$ sangat tidak suka; $2=$ tidak suka; $3=$ agak suka; $4=$ suka; $5=$ sangat suka

\section{Organoleptik Rasa Sosis}

Rasa pada suatu makanan atau minuman mempunyai peranan penting, sebab dengan rasa maka konsumen dapat mengetahui dan menilai apakah makanan atau minuman tersebut enak atau tidak. Hasil uji organoleptik rasa sosis dengan perbandingan daging sapi jamur tandan kosong kelapa sawit (300 gram : 100 gram), (200 gram : 200 gram) dan (100 gram : 300 gram) serta perlakuan perbandingan tepung tapioka : tepung talas termodifikasi (30\%: $0 \%)$ dan $(15 \%$ : 15\%) ditampilkan pada tabel 4.

Tabel 4. menjelaskan nilai rerata uji organoleptik rasa sosis, dimana perlakuan kontrol dan perbandingan daging sapi : jamur tandan kosong kelapa sawit (300 gram : 100 gram) dengan penambahan tepung tapioka : tepung talas termodifikasi (30\%: 0\%) dan ( $15 \%$ : $15 \%)$ tidak berbeda nyata, akan tetapi berbeda nyata pada perlakuan perbandingan daging sapi : jamur tandan kosong kelapa sawit (100 gram : 300 gram) dengan penambahan tepung tapioka : tepung talas termodifikasi (30\%: $0 \%)$ dan $(15 \%: 15 \%)$ pada taraf singnifikansi $5 \%$.

Rerata hasil uji organoleptik rasa sosis dengan perbandingan daging sapi : jamur tandan kosong kelapa sawit dan penambahan tepung tapioka : tepung talas termodifikasi berkisar antara 3,30 (agak suka) hingga 4,30 (suka). Perlakuan dengan perbandingan daging sapi : jamur tandan kosong kelapa sawit (400 gram : Ogram) dengan penambahan tepung 
tapioka : tepung talas termodifikasi $(30 \%$ : $0 \%$ menunjukkan penilaian tertinggi yaitu 4,30 (suka), Secara umum sosis memiliki rasa gurih yang khas. Menurut Farikhah dan Badrul (2013) rasa yang terbentuk pada sosis selain diperoleh dari penambahan daging ayam maupun sapi juga diduga disebabkan oleh penggunaan bahan pangan lain. Penggunaan jamur tandan kosong kelapa sawit dalam proses pembuatan sosis mempengaruhi rasa sosis. Selain itu menurut Hartono (2011) bahwa kandungan lemak yang terdapat pada produk makanan dapat berpengaruh terhadap rasa bahan makanan, sebab adanya lemak akan memperbaiki rasa dari suatu bahan makanan.

\section{Organoleptik Tekstur Sosis}

Tekstur merupakan sensasi tekanan yang dapat diamati dengan mulut (pada waktu digigit, dikunyah dan ditelan) ataupun perabaan dengan jari (Kartika, 1988). Tekstur juga dapat menentukan suatu produk diterima atau tidak oleh konsumen. Hasil uji organoleptik aroma rasa sosis dengan perbandingan daging sapi : jamur tandan kosong kelapa sawit (300 gram : 100 gram), (200 gram : 200 gram) dan (100 gram : 300 gram) serta perlakuan perbandingan tepung tapioka : tepung talas termodifikasi (30\%:0\%) dan (15\%: 15\%) ditampilkan pada tabel 5.

Tabel 4. Rerata Uji Organoleptik Rasa Sosis

\begin{tabular}{|c|c|c|}
\hline Perlakuan & \multicolumn{2}{|c|}{ Rasa } \\
\hline Daging Sapi : Jamur Tandan & \multicolumn{2}{|c|}{$\begin{array}{c}\text { Tepung Tapioka : Tepung Talas } \\
\text { Kosong Kelapa Sawit }\end{array}$} \\
\cline { 2 - 3 } & $30 \%: 0 \%$ & $15 \%: 15 \%$ \\
\hline 400 gram : 0 gram (kontrol) & $4,30^{\mathrm{a}}$ & $4,15^{\mathrm{a}}$ \\
\hline 300 gram : 100 gram & $4,10^{\mathrm{a}}$ & $3,75^{\mathrm{ab}}$ \\
\hline 200 gram : 200 gram & $3,70^{\mathrm{ab}}$ & $3,30^{\mathrm{b}}$ \\
\hline 100 gram : 300 gram & $3,45^{\mathrm{b}}$ & \multicolumn{2}{|c|}{} \\
\hline
\end{tabular}

Ket : Angka yang diikuti oleh kode huruf yang berbeda menunjukkan adanya perbedaan yang nyata pada taraf signifikansi $5 \%$.

Ket Skala : $1=$ sangat tidak suka; $2=$ tidak suka; $3=$ agak suka; $4=$ suka; $5=$ sangat suka 
Tabel 5. Rerata Uji Organoleptik Tekstur Sosis

\begin{tabular}{|c|c|c|}
\hline Perlakuan & \multicolumn{2}{|c|}{ Tekstur } \\
\hline Daging Sapi : Jamur Tandan & $\begin{array}{r}\text { Tepung Tapioka : Tepung Talas } \\
\text { Kosong Kelapa Sawit }\end{array}$ & \multicolumn{2}{|c|}{ Termodifikasi } \\
\cline { 2 - 3 } & $50 \%: 0 \%$ & $15 \%: 15 \%$ \\
\hline 400 gram : 0 gram (kontrol) & $4,40^{\mathrm{a}}$ & $4,10^{\mathrm{a}}$ \\
\hline 300 gram : 100 gram & $4,15^{\mathrm{a}}$ & $3,65^{\mathrm{b}}$ \\
\hline 200 gram : 200 gram & $3,55^{\mathrm{bc}}$ & $3,00^{\mathrm{d}}$ \\
\hline 100 gram : 300 gram & $3,25^{\mathrm{cd}}$ & \\
\hline
\end{tabular}

Ket : Angka yang diikuti oleh kode huruf yang berbeda menunjukkan adanya perbedaan yang nyata pada taraf signifikansi $5 \%$.

Ket Skala $: 1=$ sangat tidak suka; $2=$ tidak suka; $3=$ agak suka; $4=$ suka; $5=$ sangat suka

Tabel 5 menjelaskan rerata uji organoleptik tekstur sosis, dimana perlakuan kontrol dan perbandingan daging sapi : jamur tandan kosong kelapa sawit $(300$ gr : 100 gr $)$ dengan penambahan tepung tapioka $(30 \%: 0 \%)$ dan $(15 \%: 15 \%)$ tidak menunjukkan perbedaan yang nyata akan tetapi berbeda nyata terhadap perlakuan perbandingan daging sapi : jamur tandan kosong kelapa sawit (200 gram : 200 gram) dan (100 gram : 300 gram) dengan penambaahan tepung tapioka $(30 \%: 0 \%)$ dan $(15 \%$ : $15 \%$ ) pada taraf singnifikasi $5 \%$. Rerata hasil uji organoleptik rasa tekstur berkisar antara 3,00 (agak suka) hingga 4,40 (suka).

Perlakuan perbandingan daging sapi : jamur tandan kosong kelapa sawit
(400 gram : 0 gram) dengan penambahan tepung tapioka : tepung talas termodifikasi (30\% : 0\%) menunjukan penilain panelis tertinggi yaitu 4,40 (suka) sesuai dengan hasil analisis terhadap tekstur sosis perlakuan dengan perbandingan daging sapi : jamur tandan kosong kelapa sawit (400 gram : 0 gram) dengan penambahan tepung tapioka : tepung talas termodifikasi (30\% : 0\%) yaitu $2,78 \mathrm{~mm} / \mathrm{gr}$ detik menunjukkan tekstur sosis lebih kenyal. Tekstur sosis dipengarui oleh kualitas dan jenis bahan baku (daging) yang digunakan, jenis dan persentase tepung pati serta pada proses pembuatan. Kualitas daging akan menentukan mutunya, yaitu semakin segar daging yang dipakai maka semakin bagus mutu sosis yang dihasilkan (Wibowo 2006). 
Salah satu syarat mutu sosis yang baik bisa ditinjau dari teksturnya yaitu padat dan kenyal. Selain daging bahan lain yang berperan untuk membentuk tekstur sosis adalah putih telur, fungsi putih telur sama dengan fungsi protein pada daging. Selain sebagai pengisi maupun pengikat, penggunaan tepung juga bermanfaat sebagai pembentuk tekstur. Jenis pati yang digunakan juga mempengaruhi tekstur dari sosis yang dihasilkan. Hasil analisis terhadap tekstursosis semakin rendah penggunan daging sapi dan semakin tinggi penggunaan jamur menunjukkan nilai tekstur yang semakin menurun ditandai dengan nilai tekstur yang semakin besar yang menunjukkan tekstur sosis semakin lembek dan berdasarkan penilaian organoleptik menunjukkan penilaian agak suka. Sedangkan penggunan daging sapi yang tinggi dan jamur semakin rendah menunjukkan nilai tekstur yang semakin kecil yang menunjukkan sosis semakin padat serta kenyal dan penilaian panelis berada pada skala suka. Sosis daging sapi dan jamur tandan kosong kelapa sawit pada penelitian ini disukai karena memiliki tekstur yang padat dan kenyal.

\section{KESIMPULAN}

1. Hasil analisis kandungan protein sosis dengan perlakuan perbandingan daging sapi : jamur tandan kosong kelapa sawit dan penambahan tepung tapioka : tepung talas termodifikasi berkisar antara 13,15\% hingga $16,02 \%$. Semakin rendah penggunaan daging sapi dan semakin tinggi penggunaan jamur sawit maka kandungan protein sosis semakin rendah.

2. Hasil analisis tekstur sosis dengan perlakuan perbandingan daging sapi : jamur tandan kosong kelapa sawit dan penambahan tepung tapioka : tepung talas termodifikasi berkisar antara 2,78 $\mathrm{mm} /$ gram detik hingga 4,41 $\mathrm{mm}$ /gram detik. Semakin rendah penggunaan daging sapi dan semakin tinggi penggunaan jamur tandan kosong kelapa sawit maka tekstur sosis semakin lunak atau tidak kenyal.

3. Hasil penilaian uji organoleptik terhadap warna sosis tidak berbeda nyata pada semua perlakuan, panelis menilai warna sosis pada skala suka. Penilaian rasa sosis dengan rerata berkisar antara antara 3,30 (agak suka) hingga 4,30 (suka). Penilaian rerata tekstur sosis berkisar antara 3,00 (agak suka) hingga 4,40 (suka).

\section{DAFTAR PUSTAKA}

Badan Standarisasi Nasional (BSN). 2005. SNI Sosis Daging (SNI 01-3820- 
1995). Badan Standarisasi Nasional, Jakarta.

DKBM, 2005. Daftar Komposisi Bahan Makanan Untuk Kalangan Sendiri. Program Studi Gizi Fakultas Ilmu Kedokteran Universitas Muhamadiyah Surakarta.

Farikhah dan Badrul. 2013. Sosis. Familia (Grup Relasi Inti Media, Anggota IKAPI). Yogyakarta.

Fitriya S. K. 2012 Karakteristik Tepung Talas Termodifikasi (Colocasia esculenta ( $l$ ) schott) dan Pemanfaatannya dalam Pembuatan Cake. Fakultas Pertanian Skripsi IPB Bogor.

Haryadi. 2011. Teknologi Modifikasi Tepung Kasava. Jurnal Agritech Vol 31 (2) : 86-92

Hayuningsih, Sarbini dan Kurnia. 2009. Perbedaan Kandungan Protein, Zat Besi dan Daya Terima pada Pembuatan Bakso dengan Perbandingan Jamur Tiram (Pleurotus Sp) dan Daging Sapi yang Berbeda. Dalam Jurnal Kesehatan.Vol.2 No.1.

Indriyani, F, Nurhidajah, A. Suyanto. 2013. Karakteristik Fisik, Kimia dan Sifat Organoleptik Tepung Beras Merah Berdasarkan Variasi Lama Pengeringan. Jurnal Pangan dan Gizi Vol. 04 No. 08 Tahun 2013
Kartika B., Pudji, H. dan Wahyu, S. 1988. Pedoman Uji Inderawi Bahan Pangan. Universitas Gajah Mada. Yogyakarta

Rahmawati, W, Y.A. Kusumastuti, dan N Aryanti. Karakteristik Pati Talas (Colocasia esculenta) sebagai Alternatif Sumber Pati Industri di Indonesia. Jurnal Teknologi Kimia dan Industri Vol. 1 No. 1 Tahun 2012

Richana, N., 2012. Araceae dan Dioscorea : Manfaat Umbi-Umbian Indonesia. Nuansa. Bandung

Soeparno. 1998. Ilmu dan Teknologi Daging. UGM Press Yogykarta

Sudarisman T. dan A.R. Elvina. 1996. Petunjuk Memilih Produk Ikan dan Daging.Cetakan I. PT. Penebar Swadaya.Jakarta

Sudrajat, G. 2007. Sifat Fisik Dan Organoleptik Bakso Daging Sapi dan Daging Kerbau Dengan Penambahan Karagenan dan Khitosan. Skripsi. Fakultas Pertanian, Institut Pertanian Bogor. Bogor

Suprapti, L.2005. Teknologi Pengolahan Pangan Tepung Tapioka dan Pemanfaatannya. PT Gramedia Pustaka Jakarta

Wibowo S. 2006. Pembuatan Bakso Ikan dan Bakso Daging. Penebar Swadaya. Jakarta 